\title{
STRENGHT AND DURABILITY ASPECTS OF RECYCLED AGGREGATE CONCRETE
}

\author{
S. Gangaram ${ }^{1}$, V. Bhikshma ${ }^{2}$, M. Janardhana ${ }^{3}$ \\ ${ }^{I}$ Research Scholar, Jawaharlal Nehru Technological University, Hyderabad, Telanagana, India \\ ${ }^{2}$ Professor of Civil Engineering, University College of Engineering, Osmania University, Hyderabad, Telangana, \\ India \\ ${ }^{3}$ Professor of Civil Engineering, Jawaharlal Nehru Technological University Hyderabad, Telangana, India
}

\begin{abstract}
The increasing difficulty in securing natural coarse and fine aggregates for the production of concrete coupled with the environmental issues and unlimited extraction of natural aggregates makes the usage of recycled aggregate concrete (RAC) is the prime importance to protect the planets future. However the full use of the material can be justified only through structural applications. Engineers are reluctant to use RCA in structural applications due to lack of design information. In this article, attempt has been made to investigate the strength and durability aspects of Recycled Aggregate Concrete (RAC). Basic characteristics of recycled aggregates were determined in the laboratory. Concrete of $M_{20}, M_{30}$, and $M_{40,} M_{50}, M_{60}$ and $M_{70}$ grades were designed. The properties of fresh and hardened recycled aggregate concrete were evaluated. The results of compressive strength test, split tensile strength, flexural strength, and permeability tests are presented in this paper.
\end{abstract}

Keywords: Sustainable Buildings, durability, Recycled Aggregates, Structural Design, Design Codes, Compressive strength, flexural strength, splitting tensile strength.

\section{INTRODUCTION}

The increasing number of concrete buildings being demolished, the difficulties of disposing of concrete rubble produced together with a developing scarcity of aggregate need to the major urban areas has prompted an interest in the possibility of using concrete rubble as aggregate in concrete. Due to rapid growth in construction industry, continuous depletion found in natural resources which has severe impact on environment. As per the statistics of the World Bank published in Enaadu Telugu news paper, the Delhi $58750 \mathrm{KN}$ and Mumbai $53900 \mathrm{KN}$ are generating daily waste, and ranked 9 and 10 among top ten cities in the World. India has $4^{\text {th }}$ place in the World for generation of daily waste material. As per the World Bank report, Delhi (58750KN), Mumbai (53900 KN), Chennai (26690 KN), Hyderabad $(21910 \mathrm{KN})$, Bangalore (16780 KN), Ahmadabad (13020 KN), Kanpur (10970 KN), Agra (6500 $\mathrm{KN})$ and Indore $(5600 \mathrm{KN})$ are the few cities in India which generate daily wastes. It is worthy to mention that, $50 \%$ is the building rubble in daily waste. In this context investigation on strength and durability of recycled aggregate concrete has significant role to use waste material as aggregate.

\section{EXPERIMENTAL WORK}

Six different mixes were considered in this experimental investigation. Properties of cement, fine aggregate, natural and recycled aggregates were investigated. For all the six mixes, $100 \%$ recycled aggregates were considered.

\section{MATERIALS}

\subsection{Cement}

Ordinary Portland cement of 53 grade confining to IS: 12269 were used. It was tested for its physical properties as per IS: 4031(part-II)-1988. And specific gravity and fineness are found to be 3.15 and 3.10 .

\subsection{Fine Aggregates}

Fine aggregate obtained from local market was used. The physical properties of fine aggregate such as specific gravity, fineness modulus was determined in accordance with IS: 2386-1963. Specific gravity and fineness modulus of fine aggregate were found to be 2.56 , and 2.95 .

\subsection{Coarse Aggregates}

Recycled aggregates were obtained from random samples of different grades and ages from laboratory waste. Recycled aggregate of $\max 20 \mathrm{~mm}$ was used. Specific gravity of recycled coarse aggregate is 2.727 . The water absorption capacity of natural aggregates and recycled aggregate in the mixture represents one of the main differences between recycled and natural aggregate. The water absorption values of natural and recycled aggregates were found to be $0.50 \%$ and $2.61 \%$.

\subsection{Water}

Potable water which is free from chemicals and organic materials was used for the study. 


\section{MIX PROPORTIONING}

The mix design was done as per IS: 10262 (2009) for $\mathrm{M}_{20}$, $\mathrm{M}_{30}$, and $\mathrm{M} 40, \mathrm{M}_{50}, \mathrm{M}_{60}$ and $\mathrm{M}_{70}$ with Entroy and shock lock method. The grade of concrete adopted for this study is $\mathbf{M}_{20}$, $\mathrm{M}_{30}$, and $\mathrm{M} 40, \mathrm{M}_{50}, \mathrm{M}_{60}$ and $\mathrm{M}_{70}$. Maximum size of aggregate taken is $20 \mathrm{~mm}$ and grading of sand is zone II. Different water cement ratios adopted for various concrete mixes and mix proportion was carried out for a slump of 100 $\pm 25 \mathrm{~mm}$. The quantity of materials required for $1 \mathrm{~m}^{3}$ of conventional $\mathrm{M}_{20}, \mathrm{M}_{30}$, and $\mathrm{M} 40, \mathrm{M}_{50}, \mathrm{M}_{60}$ and $\mathrm{M}_{70}$ concrete mix are given Table 4.

\section{SPECIMEN PREPARATIONS}

150x150x150 mm cubes, 100x100x500mm beams and 300 $\mathrm{x} 150 \mathrm{~mm}$ diameter cylinder specimens were cast to determine the compressive strength, flexural strength and splitting tensile strength of the concretes. All specimens were cast in steel molds and compacted by using mechanical vibration. After casting, the specimens were cured in air for a period of $24 \mathrm{~h}$, and then removed from mold. The specimens were cured for 7 and 28 days in a water tank at normal temperature.

\section{TESTS ON FRESH AND HARDENED CONCRETE}

\subsection{Fresh Properties}

Fresh properties of concrete studied on

- Slump test

- Compaction factor test.

Slump test and compaction factor tests were done on fresh concrete to test the consistency of fresh concrete.

\subsection{Mechanical Properties on Hardened Concrete}

The mechanical properties of concrete were investigated on

- Compressive strength

- Flexural strength

- Splitting tensile strengths

- Permeability test

After curing, the cubes and cylinder specimens were tested in the compression testing machine. Third point loading method is used for testing beams. Cubes were tested at 7 and 28 days. Cylinders and beams were tested at 28days. Three specimens were considered per each test at 7 and 28days age of concrete.

\section{TEST RESULTS OF VARIOUS MIXES}

Recycled Aggregate Concrete Mix: Using the mix proportions recycled aggregate concrete of grade $\mathrm{M}_{20}, \mathrm{M}_{30}$, $\mathbf{M}_{40}$ and $\mathbf{M}_{50} \mathbf{M}_{60}$ and $\mathbf{M}_{70}$ mixes as given in table 4 , the mixes were prepared and tested on fresh and hardened properties of concrete. Results are tabulated below.

\subsection{Slump Test}

Showed a slump of $75-100 \mathrm{~mm}$ for all the six mixes

\subsection{Compaction Factor Test}

Compaction factor value for all the six mixes were between 0.91-0.76.

\subsection{Compressive Strength}

The compressive strength results are presented in Table 5. Each presented value is the average of three measurements. It is shown in Fig.1, that compressive strength of RAC is not achieved for $\mathrm{M}_{40}$ and above grades. The concrete mixtures prepared with $100 \%$ replacement of RA had a decrease of the compressive strength at 28-day for $\mathrm{M}_{40}$ and above grades of concrete. RAC could not achieve target strength for $\mathbf{M}_{40}$ and above grades of concrete. The higher compressive strength may be attributed to the greater bonding force and strength when similar types of aggregates were used. Normally as RA replacement increased, compressive strength will decrease (Topcu and Sengel (2004) and Kou, Poon and Chan (2007)).

\subsection{Flexural Strength}

Flexural strength of plain recycled concrete (PRC) beams was investigated for different grades of concrete. Experimental results tabulated below.

\subsection{Splitting Tensile Strength}

Splitting tensile strength of plain recycled concrete (PRC) specimens was investigated for different grades of concrete. Experimental results tabulated below.

\subsection{Permeability Test}

Continuous uniform pressure applied @ 78.40N and the permeability of recycled concrete is more compared to the natural aggregate concrete, further; change in fraction of aggregates may improve the permeability characteristics of recycled aggregate concrete.

From table 4 , the compressive strength of $\mathrm{M}_{20} \& \mathrm{M}_{30}$ grade concretes were achieved target strengths and M40 and above grades were not achieved. Further, to achieve target strength for above M40 \& above grades; the fraction of aggregates may be changed. Also flexural and splitting tensile strength values can be improved by changing fraction of aggregate for M40 \& above grades.

\section{MIX WITH REPLACEMENT OF NATURAL COARSE AGgREGATES WITH RECYCLED COARSE AGGREGATES}

Different mixes were made by replacing $100 \%$ of natural coarse aggregates with recycled coarse aggregates. Mixes were tested for fresh properties and mechanical properties. Results are tabulated below. Fig 1, Variation of compressive strength at 28days for different grades of concrete mixes is 
shown. Fig2. Variation of flexural strength at 28days for different grades of concrete mixes is shown. Fig 3. Variation of splitting tensile strength at 28days for different grades of concrete mixes is shown. From table 4, 5 \& 6 figs 1, 2, 3, though splitting tensile strength values at 28days were less, compressive and flexural strength values at 28 days are more for RA compared with target strength of $\mathrm{M}_{20} \& \mathrm{M}_{30}$ grades of concrete. So, for further test $100 \%$ of NA can be replaced with different fraction recycled coarse aggregates.

\section{CONCLUSION}

Based on this experimental study, the following conclusions are drawn.

When workability of recycled coarse aggregates was tested using slump test and compaction factor test, the mix shows not adequate workability.

Compressive strength, flexural strength and splitting tensile strength values of concrete mix with recycled aggregates were less for $\mathrm{M}_{40}$ and above grades compared with their target strength.

The study shows that $100 \%$ replacement of recycled coarse aggregates for natural aggregate gives satisfactory strength for $\mathrm{M}_{20} \& \mathrm{M}_{30}$. So the replacement is of much benefit and shall be encouraged to achieve higher grades of concrete.

\section{REFERENCES}

[1] M.L. Berndt, "Properties of sustainable concrete containing fly ash, slag and recycled concrete aggregate", Construction and Building Material, 2009

[2] Vlastimir Radonjanin , Mirjana Malesev, Snezana Marinkovic , Ali Emhemd Saed Al Malty "Green recycled aggregate concrete", Construction and Building materials ,2013

[3] Khaldoun Rahal, "Mechanical properties of concrete with recycled coarse aggregate", Building and Environment ,2007

[4] Amnon Katz,'Properties of concrete made with recycled aggregate from partially hydrated old concrete", Cement and concrete research, 2003

[5] IS 10262 - 2009, Concrete mix proportioning Guidelines, Bureau of Indian standard, July 2009, New Delhi.

[6] M.S Shetty, "Concrete technology, theory and practice", Revised edition, S chand and company Ltd, 2005.

[7] A.M. Neville, "Properties of Concrete", fourth edition, Ninth Impression 2011, Pearson(India) Ltd.
Table 1. Properties of cement

\begin{tabular}{|c|c|}
\hline Name of test & Result \\
\hline Specific gravity & 3.15 \\
\hline Standard consistency & $34 \%$ \\
\hline Initial setting time & 40 minutes \\
\hline
\end{tabular}

Table 2. Material properties of fine aggregates

\begin{tabular}{|c|c|}
\hline Name of test & Test Results \\
\hline Specific gravity & 2.74 \\
\hline Water Absorption (\%) & 0.8 \\
\hline Water content (\%) & 3.1 \\
\hline Bulk Density (kg/l) & 1.73 \\
\hline Percentage Voids (\%) & 38.73 \\
\hline
\end{tabular}

Table 3. Quantity of materials

\begin{tabular}{|l|l|l|l|l|l|l|}
\hline \multirow{2}{*}{ Material } & \multicolumn{6}{|c|}{ Quantity $\left(\mathrm{kg} / \mathrm{m}^{3}\right)$} \\
\cline { 2 - 7 } & $M_{20}$ & $M_{30}$ & $M_{40}$ & $M_{50}$ & $M_{60}$ & $M_{70}$ \\
\hline Cement & 370.00 & 424.00 & 475.00 & 490.00 & 588.00 & 565.00 \\
\hline Fine aggregate & 673.83 & 656.00 & 655.30 & 491.00 & 477.50 & 424.00 \\
\hline Coarse aggregate & 111.20 & 1082.00 & 1081.40 & 1252.50 & 1170.00 & 1271.00 \\
\hline Water & 185.00 & 186.60 & 171.00 & 176.40 & 188.20 & 169.50 \\
\hline
\end{tabular}

Table 4. Compressive strength

\begin{tabular}{|c|c|c|}
\hline \multirow{2}{*}{ Design Mix } & \multicolumn{2}{|c|}{ Compressive strength(Mpa) } \\
\cline { 2 - 3 } & 7-days & 28-days \\
\hline $\mathrm{M}_{20}$ & 20.70 & 36.00 \\
\hline $\mathrm{M}_{30}$ & 24.89 & 40.74 \\
\hline $\mathrm{M}_{40}$ & 28.89 & 32.74 \\
\hline $\mathrm{M}_{50}$ & 26.52 & 30.37 \\
\hline $\mathrm{M}_{60}$ & 24.00 & 37.18 \\
\hline $\mathrm{M}_{70}$ & 46.96 & 46.81 \\
\hline
\end{tabular}


Table 5. Flexural strength

\begin{tabular}{|c|c|}
\hline \multirow{2}{*}{ Design Mix } & Flexural strength(Mpa) \\
\cline { 2 - 2 } & 28days \\
\hline$M_{20}$ & 3.182 \\
\hline$M_{30}$ & 3.036 \\
\hline$M_{40}$ & 3.686 \\
\hline$M_{50}$ & 3.832 \\
\hline$M_{60}$ & 3.734 \\
\hline$M_{70}$ & 4.198 \\
\hline
\end{tabular}

Table 6. Splitting tensile strength

\begin{tabular}{|c|c|}
\hline \multirow{2}{*}{ Design Mix } & Splitting strength(Mpa) \\
\cline { 2 - 3 } & 28 -day \\
\hline $\mathrm{M}_{20}$ & 1.792 \\
\hline $\mathrm{M}_{30}$ & 2.163 \\
\hline $\mathrm{M}_{40}$ & 2.281 \\
\hline $\mathrm{M}_{50}$ & 2.781 \\
\hline $\mathrm{M}_{60}$ & 2.901 \\
\hline $\mathrm{M}_{70}$ & 2.789 \\
\hline
\end{tabular}

Table 7. Permeability test

\begin{tabular}{|c|c|}
\hline Design Mix & Permeability of coefficient $(\mathrm{m} / \mathrm{s})$ \\
\hline$M_{20}$ & $1.25 \times 10^{-5}$ \\
\hline$M_{30}$ & $1.79 \times 10^{-5}$ \\
\hline$M_{40}$ & $1.72 \times 10^{-5}$ \\
\hline$M_{50}$ & $1.90 \times 10^{-5}$ \\
\hline$M_{60}$ & $1.17 \times 10^{-5}$ \\
\hline$M_{70}$ & $1.11 \times 10^{-5}$ \\
\hline
\end{tabular}

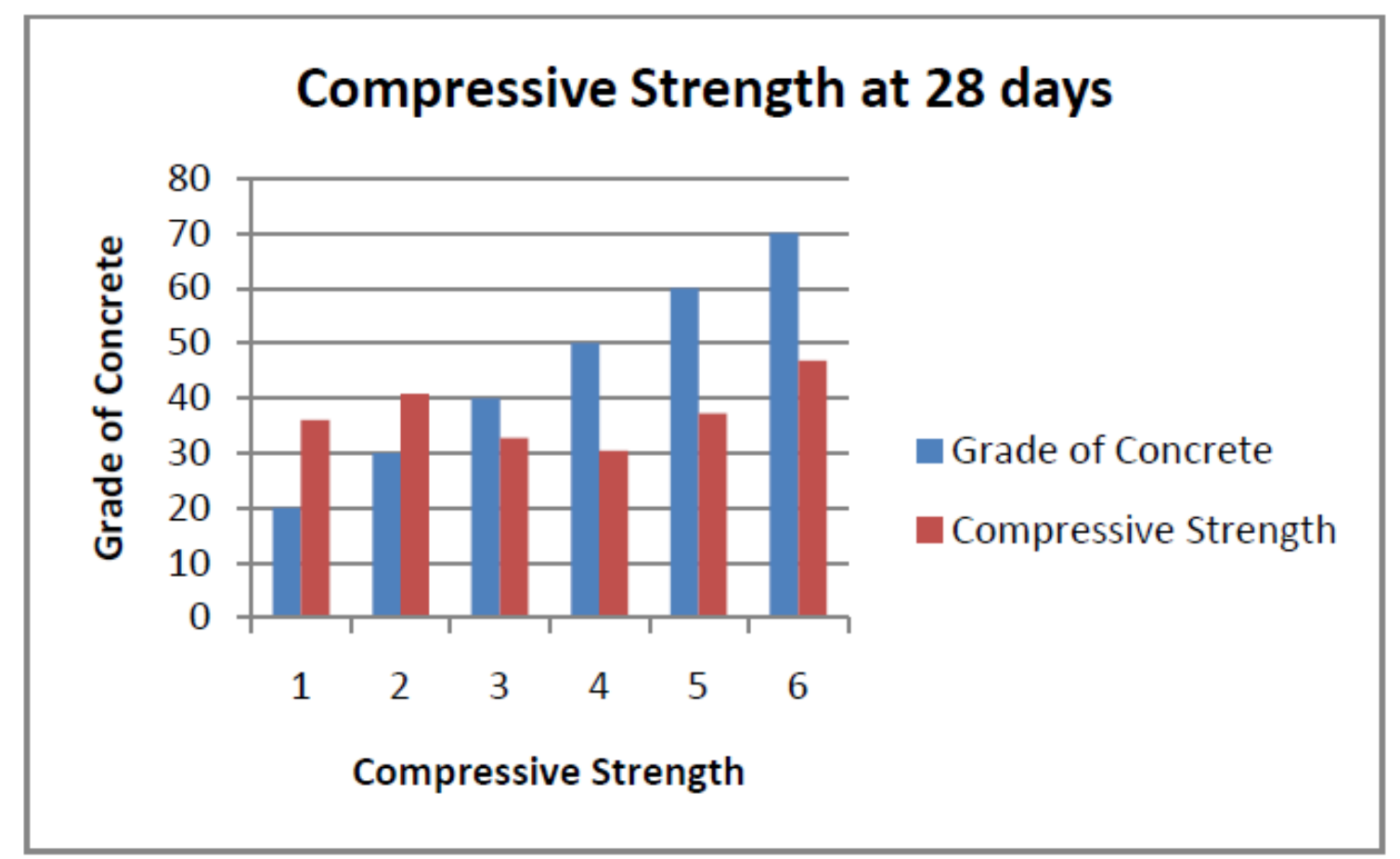

Fig 1. Variation of compressive strength at 28days 


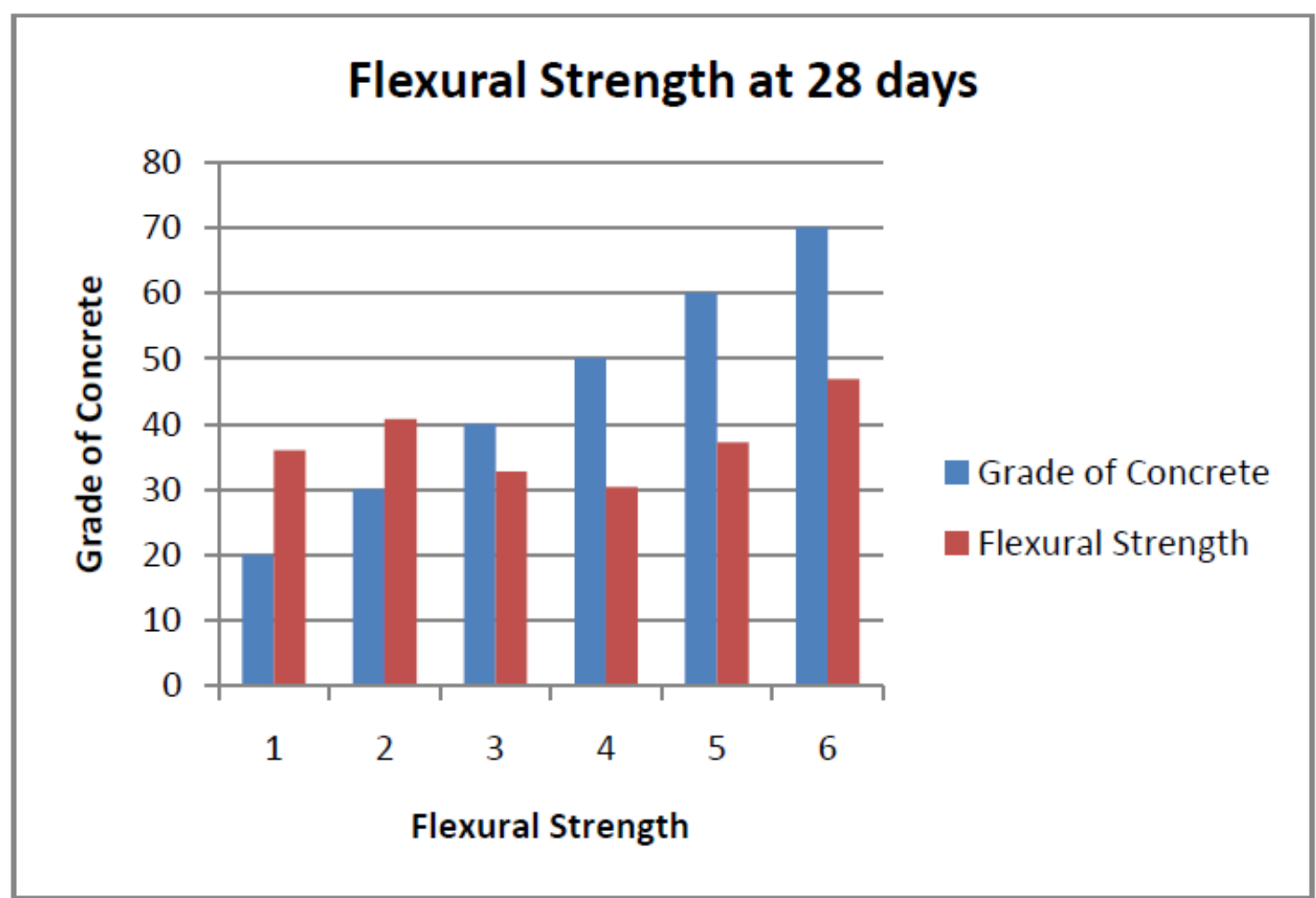

Fig 2. Variation of flexural strength at 28days

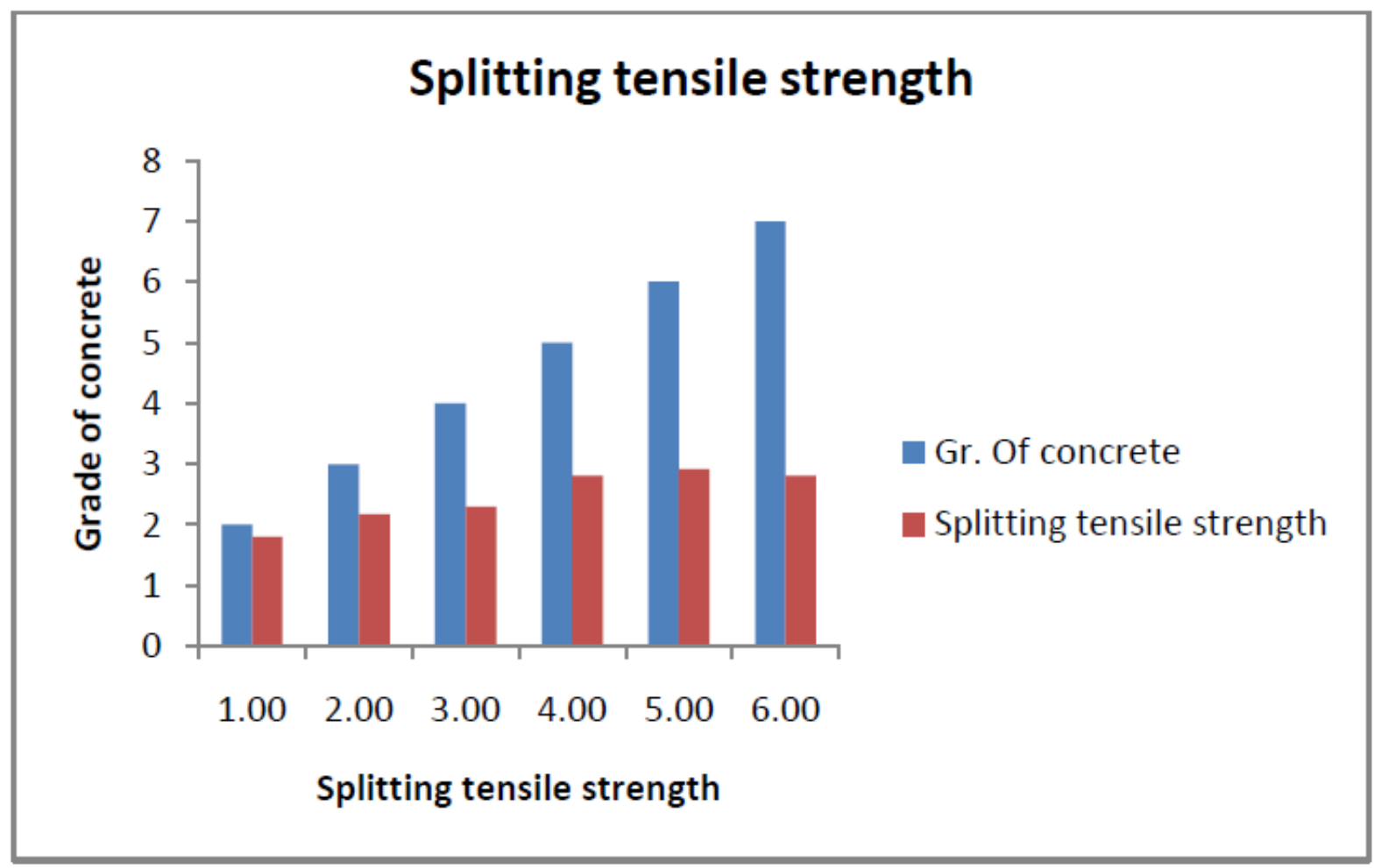

Fig3. Variation of splitting tensile strength at 28days 